\title{
Scientific and Philosophical Concept of Unity of The Universe
}

\section{Vahram R Sargsyan}

President of the International Academy of Neuroscience and Research associate L.A. Orbeli Institute of Physiology, Yerevan, Republic of Armenia

Corresponding Author: Vahram R Sargsyan, President of the International Academy of Neuroscience and Research associate L.A. Orbeli Institute of Physiology, Yerevan, Republic of Armenia

E-mail: sargsyan.vahram@gmail.com

\section{Received date: August 26, 2019; Accepted date: Septembe 13, 2019; Published date: September 17, 2019}

Citation: Vahram R Sargsyan (2019) Scientific and Philosophical Concept of Unity of The Universe. J.Neuroscience and Neurological Surgery. 4(4); DOI: 10.31579/2578-8868 /085

Copyright: @ 2019 Vahram R Sargsyan. This is an open-access article distributed under the terms of The Creative Commons Attribution License, which permits unrestricted use, distribution, and reproduction in any medium, provided the original author and source are credited.

\begin{abstract}
This paper proposes a new scientific and philosophical concept of the unity of the universe. The concept is based on new biological theories (13 viral theories and one genetic theory) developed in 2018 - 2019 in Yerevan. The issues of materialism, idealism and dualism are discussed. And also the question of the primacy of matter and consciousness is analyzed. This is very important for a correct understanding of the processes occurring in the brain and the formation of the higher nervous activity of a person.

Keywords: scientific and philosophical concept, unity, materialism, idealism, dualism, brain, higher nervous activity.
\end{abstract}

\section{Introduction}

Philosophy is a special form of cognition of the world, developing a system of knowledge about the most general characteristics, ultimate generalizing concepts and fundamental principles of reality (being) and cognition, being of a person, about the relation of a person and the world [2]. The tasks of philosophy throughout its history included both the study of the universal laws of the development of the world and society, and the study of the process of cognition and thought, as well as the study of moral categories and values. The ultimate philosophical questions include, for example, the questions "Do we know the world?", "Does God exist?", "What is truth?", "What is Man?", "What is primary - matter or consciousness?" And others [ one]. In this article we will discuss and try to give a scientifically substantiated answer to the question - "What is matter or consciousness primarily?", And also find out how relevant this question is, is it too artificial and not necessary in principle for the development of philosophy and science as a whole. This is very important for the further intensive and proper development of neurobiology.

For many centuries there has been a debate between the materialistic and idealistic approach to the structure of the universe. According to the materialistic approach, matter is primary. According to an idealistic approach - the primary idea.

Idealism is a way of explaining which considers the spiritual prior to the material, while materialism considers the material prior to the

spiritual. Idealism believes that everything material supposedly depends on something spiritual and is determined by it, while materialism claims that everything spiritual depends on the material and is determined by it.

At its core, idealism is religion, theology. "Idealism is clericalism" [4], - said Lenin. All idealism is a continuation of the religious approach to solving any issue, even if individual idealistic theories have dropped their religious shell. Idealism cannot be separated from superstitions, belief in the supernatural, mysterious and unknowable.

On the contrary, materialism seeks to explain these issues on the basis of the material world, with the help of factors that can be checked, understood and controlled.

The ideas of supernatural and religious ideas owe their origin to the helplessness of people before the forces of nature and their ignorance. Forces that people cannot understand are personified in their representation with the powers of certain spirits or gods, i.e. with supernatural beings that cannot be known. Every religion and every idealism is based on a similar doubling of the world. They are dualistic and invent the ideal, or supernatural world, which dominates the real, material world.

For idealism, there always exists a higher, supposedly more real nonmaterial world, which precedes the material world, is its final source and cause; and to which the material world is subordinate. For materialism, on the contrary, there is only one world - the material world, the one in which we live.

In philosophy, there are many different attempts to find a compromise between idealism and materialism. One such compromise attempt is well known under the name of "dualism." This philosophy, like any idealistic philosophy, believes that there is a spiritual that is independent and different from the material, but unlike idealism, it tries to assert the equivalence of the spiritual and material. So, she interprets the world of inanimate matter purely materialistically: from her point of view, only natural forces act in it, and spiritual factors are and act outside its borders and have nothing to do with it. But when it comes to explaining consciousness and society, here, this philosophy declares, already an area of the spirit. In social life, she argues, an idealistic rather than materialistic explanation must be sought. This compromise between materialism and idealism, therefore, is equivalent in essence to the fact that such philosophers and their supporters remain idealists, since in all the most 
important questions about man, society and history, they continue to adhere to idealistic views as opposed to materialistic ones. Such a duality of worldview in bourgeois society is characteristic, for example, of the technical intelligentsia. The profession forces its representatives to be materialists, but only at work. In matters relating to society, these people often remain idealists [3].

Below are the main points of idealism and materialism, as well as their opposite.

The main points put forward by any form of idealism can be formulated as follows [3]:

1. Idealism claims that the material world depends on the spiritual.

2. Idealism claims that spirit, or mind, or idea can and does exist separately from matter. (The most extreme form of this statement is subjective idealism, which believes that matter does not exist at all and is a pure illusion).

3. Idealism asserts that there is a region of the mysterious and unknowable, "above" or "beyond" or "behind" that which can be established and cognized through perceptions, experience and science.

In turn, the main provisions of materialism can be summarized as follows:

1. Materialism teaches that the world is material by its very nature, that everything that exists appears on the basis of material causes, arises and develops in accordance with the laws of motion of matter.

2. Materialism teaches that matter is an objective reality that exists outside and independent of consciousness, and that the spiritual does not exist at all separately from the material, but everything spiritual or conscious is a product of material processes.

3. Materialism teaches that the world and its laws are fully knowable and that, although much can be unknown, there is nothing that cannot be known.

As you can see, all the basic principles of materialism are completely opposite to the basic principles of idealism. The opposition of materialism to idealism, now expressed in its most general form, is not the opposite of abstract theories about the nature of the world, but the opposite between different ways of understanding and interpreting any issue. That is why it is so important.

Based on the latest advances in cell biology and neuroscience, we propose a new scientific and philosophical concept. This is a scientific and philosophical concept of the unity of the universe.

Given the fact that our scientific and philosophical concept appeared on the basis of new biological theories (13 viral theories and genetic theory), then the method used to create a new concept is the scientific method used to create new biological theories. Biological theories published in 2018 -2019. [5], [6], [7], [8], [9]. For this, we used the method of scientific meta-analysis. Reliable scientific information was analyzed, starting mainly from 1839 . Further, on the basis of the synthesis of this scientific information, we have new progressive and innovative scientific theories, and later a new scientific and philosophical concept of the unity of the universe.

\section{Research Results and Discussion}

Everything that is known to mankind and at the same time that a person can perceive with his senses (receptors) and through modern equipment is considered to be material. And all the dreams, ideas of people that today are not perceived by the human senses (receptors) or by modern technical means are considered ideal. However, with the development of science, more and more concepts and phenomena from the ideal world pass into the material world. For example, with the discovery of electromagnetic radiation, it became clear that many previously mysterious phenomena have a material basis. With the development of genetics, it became known that the material carriers of hereditary information are nucleic acids (DNA, RNA). With the development of microbiology and virology, the material causes (pathogens) of various infectious diseases, which were previously interpreted as the effects of "evil spirits" on the body, became known.

Our work in the field of neurogenetics and neurophysiology has shown that DNA viruses (biocommunicators) are responsible for the formation of long-term memory and the formation of higher nervous activity in humans and animals. This is evidenced by our biological theories (the viral theory of information perception, the viral theory of memory formation, the viral theory of the functioning of the somatic / autonomous nervous system, the nano-mock theory of the functioning of the genome and others). It was this discovery, together with our other biological theories [5], [6], [7], [8], [9] that pushed us to create a new philosophical concept of the unity of the universe. In other words, what was previously considered ideal (thoughts, emotions, the mind and consciousness of a person) has already begun to be explained at the level of DNA / RNA macromolecules and proteins.

Thus, over time, everything ideal is transformed into material (Figure 1). However, if we hypothetically imagine that everything that exists in nature is material, then it as a separate category will automatically cease to exist, for the simple reason that it will lose its opponent. In fact, everything that we will have will become the only one. Therefore, the division into material and ideal will not make sense. And the question "what is primary, matter or idea?" Will completely lose its significance.

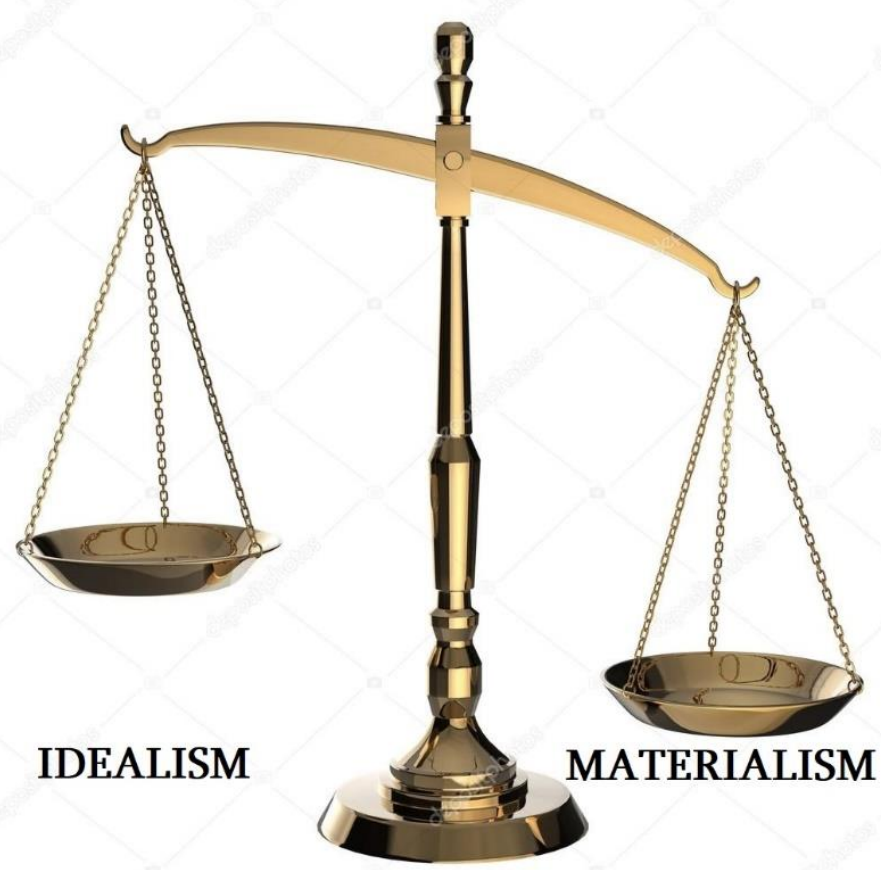

Figure 1: Philosophical scales. With the development of science, a lot of "mysteries of nature" or "mystical" finds its materialistic confirmation.

It turns out that in NATURE everything is really ONE. This indicates that the division into material and ideal was very artificial and practically meaningless. In addition, such a division of the world was determined on the basis of the egocentric need of a person to study all phenomena from the standpoint of their feelings, or in other words, the perception of the world by man. That is, a person is the center of the Universe and the main Judge, who determines what is considered material and what is ideal. After all, as noted above, "that which a person can perceive with his senses (receptors) and through modern equipment is considered material." But any sane scientist and philosopher will agree with me that such an understanding of the universe cannot be objective. It is subjective, because the main criterion is the person's feelings or his instrumental methods of registration, the data (indicators) of which are ultimately evaluated and interpreted by the person. 
The dualistic approach has also, in fact, completely exhausted itself and is scientifically unsound.

The struggle and contradictions between the materialistic and idealistic approach with the advent of new biological theories and the philosophical concept of the unity of the universe are over.

In fact, we can only talk about the existence of different hierarchical levels in a single universe. If the smallest unit is conventionally considered an electron, and the largest - the Universe, then these hierarchical levels (taking into account biological systems) can be conventionally represented as follows:

electron - atom - molecule - cell organelle - cell - tissue - organ organ system - organism (for example, man) - society - biocenosis - biogeocenosis - planet Earth - Solar system - Galaxy Milky Way -Universe.

Thus, at this stage of the historical development of mankind, it was BIOLOGY that became the driving force of scientific and philosophical progress. At an earlier stage in the development of mankind, this role was repeatedly played by Philosophy and Physics. Today we can even talk about the next revolution in biology, which of course will have a very positive effect on the development of such practical areas as medicine, agriculture, ecology, sociology, psychology, bioengineering and the like.

\section{References}

1. Alekseev PV, Panin AV. (2005) Philosophy. 3rd edition. Moscow: Prospect, 604 p.

2. Gritsanov AA (Chief Editor). The latest philosophical dictionary. 3rd ed., Book House. 2003. 1280 p. (World of Encyclopedias).

3. Internet site: https://work way.com/blog/2014/03/29/materializm-i-idealizm/. Materialism and idealism are the opposite ways of understanding any issue. 29/03/2014.

4. Lenin VI. (1969) Philosophical notebooks. Publishing House of Political Literature. Moscow, Volume 29.

5. Sargsyan VR (2019) New Scientific Theories - The Base for Creating Perspective Methods of Treating Different Diseases. J Brain Neursci 3: 008.

6. Sargsyan VR. (2018) Formation of Human Nervous Activity and New Biological Theories. J Brain Neursci 2: 004.

7. Sargsyan VR. (2019) Human Biocommunication System and New Health Care System. Alzheimers Res Ther 2(1): 000105.

8. Sargsyan VR. The main and acquired genome. Nano-models theory of the functioning of the genome. "INTERNATIONAL SCIENCE PROJECT". Finland. 1 part №17/2018. P. 8-13.

9. Sargsyan VR. The true place and role of viruses in nature. Viruses are migrating organelles of cells. "INTERNATIONAL SCIENCE PROJECT". Finland. 1 part №17/2018. P. 4-8. 